\title{
The Development of the Ascocarp in Lachnea cretea.
}

\author{
BY
}

\author{
H. C. I. FRASER, D.Sc. (Lond.), F.L.S. \\ (MRs. D. T. GWYNNE-VAUGHAN.)
}

Head of the Department of Botany, Birkbeck College, London.

\section{With Plates XLII and XLIII.}

ACHNE A CRE TE A, Phil., is a small, pale, buff Discomycete, beset with numerous darker hairs and described as occurring on plaster ceilings. It appeared in this laboratory in the Spring of I9I2, in the course of an attempt to obtain material of Pyronema confluens. In January, I9I2, a Petri dish of $3 \%$ agar was sprinkled while still fluid with finely powdered charcoal, and on it were placed fragments of charred stick known to have borne Pyronema confluens in the previous autumn. Various mycelia developed, and some were transferred to the double medium recommended by Claussen ('12). ${ }^{1}$ Pyronema was not found, but a few ascocarps of Ascophamus carneus developed, together with various Hyphomycetes, Bacteria, and Moulds, and the cultures were put aside.

In March one of them showed a single specimen of Lachnea cretea. New cultures were started and an abundant supply was obtained. The fungus was grown on Claussen's medium, and subsequently on $3 \%$ agar made up with decoction of plaster both with and without mineral salts.

Material was fixed, without removal from the agar, in various strengths of Flemming's fluid and in I \% solution of iodine in $\mathrm{I} .5 \%$ lithium iodide. Sections were stained chiefly with Heidenhain's haematoxylin followed by solution of erythrosin in clove oil. Uncut material was stained in a mixture of strong aqueous erythrosin and glycerine, and was mounted in glycerine jelly. Owing to the transparency of the agar it was possible to examine the archicarps in their natural position.

Unfortunately, the nuclei of this fungus are small, and cytological detail did not prove available. The archicarp, however, differs so much from that known in other members of the Pezizaceae that some account of its morphological characters seems to be desirable.

1 Outer dish, $0.05 \% \mathrm{KH}_{2} \mathrm{PO}_{4}, 0.05 \% \mathrm{NH}_{4} \mathrm{NO}_{3}, 0.02 \% \mathrm{MgSO}_{4}, 0.001 \% \mathrm{Fe}_{2}\left(\mathrm{PO}_{4}\right)_{3}$; inner dish, as above plus $2 \%$ inulin; in each case $3 \%$ agar was used, instead of the $2 \%$ recommended by Claussen, as it sets with greater certainty.

[Annals of Botany, Vo1. XXVII. No. CVII. July, I9I3.] 


\section{MyCELIUM.}

The mycelial hyphae vary very much in thickness. They branch freely, often in a dichotomous manner. In some cases they are richly septate, in others, especially in the rooting hyphae, the septa are far apart. Conspicuous granules, the so-called metachromatic granules commonly observed in Discomycetes, are present on the cross-walls. H-pieces and other anastomoses between neighbouring hyphae are of frequent occurrence (Pl. XLII, Figs. 3,4$)$. The cells contain a network of finely granular cytoplasm, and are multinucleate.

\section{Formation of ARChicarp AND Sheath.}

Usually, but not invariably, the archicarp is produced on one of the larger filaments. It forms two or three close coils and undergoes septation (Figs. 2, 7).

At this time the hypha which bears the archicarp and others in the immediate neighbourhood give rise to numerous stout, curved branches. These are the beginnings of the sheath. They grow up and invest the archicarp and the hypha which bears it, till a more or less spherical mass is produced (Figs. 4, 5, 6). Branches from increasingly remote hyphae are added as development proceeds, and rooting filaments grow downwards to form a secondary mycelium (Fig. 4).

At this stage the fruit is remarkably like the young perithecium of the simpler Pyrenomycetes or of such a mould as Aspergillus, and it is only later, when the development of the paraphyses takes place, that the distinctively discomycetous character is established.

In the meantime the archicarp has undergone further development. It grows out beyond the coiled portion as a long, sinuous, multicellular filament (Fig. 8), which grows among the cells of the sheath and ultimately protrudes far beyond them (P1. XLII, Fig. II, Pl. XLIII, Fig. I2).

At first, all the cells of the archicarp contain scattered nuclei similar to those of the vegetative hyphae (Fig. 7); a little later the nuclei in the central and terminal cells have become more numerous (Fig. 8), and still later three regions are clearly differentiated. The cells of the stalk differ little from those of the vegetative mycelium. The coiled central region is made up of three or four cells; these enlarge and their nuclei increase both in size and number. The terminal portion constitutes the trichogyne.

\section{TRICHOGYNE.}

This terminal part consists of some eight or nine cells; it becomes more or less emptied of contents, and a peculiar change takes place in the character of the transverse septa. They show a large, clear, central area (Figs. 5, II, I2), resembling in appearance the callus-pad of a sieve-tube, and staining readily with erythrosin. 
In one or two cases-as, for example, that shown in Fig. II-it is possible to make out that the callus pad is preceded by the formation of an open pore, and that a mass of granular substance is continuous from one side of the wall to the other. This stage was not often seen and represents no doubt a temporary condition.

These changes in the wall render the terminal portion of the archicarp readily recognizable in older specimens, since the pads are in marked contrast to the septa of an ordinary hypha, with their double row of 'metachromatic' granules.

By these means the terminal portion of the archicarp has been traced in its older stages, outside the young fruit, both in cut specimens (Figs. 1 I, I2) and in uncut material (Figs. 5, 6). Frequently it is found to branch near the apex (Figs. 5, 6, II), characteristic septa being found beyond the point of branching (Fig. 5). In no case were the apices fused with any other hypha, but whenever the filament could be traced to its termination, the ends were quite free.

Nevertheless, it seems inevitable to conclude that this prolongation of the archicarp is morphologically a trichogyne, and one, moreover, which has not long ceased to be functional. For in it the cross-walls become broken down, so that a free passage through wide pores is established from cell to cell. It is not out of the question that the contents of the trichogyne may empty themselves into the central part of the archicarp, and that in this way a form of pseudapogamy may replace fertilization; but no evidence of this process has been obtained.

\section{Ascogonial Region.}

In the central portion of the archicarp, the septa between the cells break down, so that a very wide passage is formed (Fig. I4) and nuclei pass readily from cell to cell (Fig. I3). All the cells may give rise to ascogenous hyphae.

In this region of the archicarp the nuclei are crowded together, and here, no doubt, they unite in pairs. But they are too small to yield really satisfactory data on this critical point, and any attempt to study their behaviour was abandoned. In the part of the ascogenous hyphae nearest the ascogonial cells the nuclei lie irregularly; in the upper parts they are arranged in single file (Fig. I5); sometimes two, sometimes three, lie close together; sometimes a single nucleus is separated from the others. There is no evidence either when the ascogenous hyphae are first formed, or, at a later stage, of an arrangement in regular pairs. By the time that the development of the ascogenous hyphae has begun, the inner cells of the sheath have grown up to form a wedge-shaped group of paraphyses, and by means of these the peridium is ultimately broken open, so that the fruit 
assumes the characteristically discomycetous form. The development of the inner layers of the sheath-the nutritive layers of the Aspergilliaceaeon one side of the fruit as paraphyses, and the regular unilateral growth of the ascogenous hyphae, are the salient points of difference between the ascocarp of the Discomycetes and that of the more primitive Aspergilliaceae.

At the base of the group of paraphyses the ascogenous hyphae give rise to asci in the usual way-by the bending over of the hypha and the growth of its penultimate cell (Fig. I4). The first division in the ascus is fairly clear and shows about eight chromosomes (Figs. I6, I7), but the small size of the later divisions makes critical work unsatisfactory, for it seems useless to study in a minute form processes which have been already observed on a larger scale. The spores are eight in number; they are uniseriate, elliptical, and unicellular.

From the outer cells of the sheath the thick-walled septate hairs characteristic of the genus Lachnea arise. The base of the hair is bulbous (Fig. I), but it was not observed to fork.

\section{Discussion。}

In the genus Lachnea two other species have been investigated. In Lachnea stercorea (Fraser, '07) the archicarp shows a multicellular stalk and a multicellular trichogyne. The ascogonial region consists of a single large, more or less spherical cell, from which alone the ascogenous hyphae arise. The trichogyne is much shorter than in Lachnea cretea and consists of shorter cells; it was not seen to protrude far beyond the sheath, and in some cases its terminal cell fused with a large oblong antheridium. The male nuclei were observed to enter the terminal cell of the trichogyne, but did not travel further. In contrast to that of Lachnea cretea, the trichogyne of Lachnea stercorea retains its contents, and the transverse septa undergo no recognizable modification.

In Lachnea scutellata (Brown, '11) there is a single ascogonial cell or ascogonium borne on a multicellular stalk. Brown describes only one cell beyond the ascogonium, but since, in his youngest specimens, the archicarp was already covered by the sheath and was examined in section, it remains possible that a longer terminal region is really present.

As far, then, as our present knowledge goes, there are among the species grouped together in the genus Lachnea three distinct types or female organ, and Lachnea cretea differs from both the others in possessing several ascogonial cells.

In this particular it differs also, among neighbouring forms, from Ascodesmis (Boudiera) nigricans (Claussen, '05), Pyronema confluens (Harper, '00 ; Claussen, '12), and Humaria granulata (Blackman and Fraser, '06), and it approximates several members of the Ascobolaceae, 
including species of Ascobolus and Ascophamus (Cutting, '09; Dodge, '12), where a series of ascogonial cells has been reported. Ascobolus furfuraceus (Welsford, '07) may possibly be regarded as an intermediate form; here several cells in the central region of the archicarp are united by pores, but ascogenous hyphae arise from only one.

The trichogyne of Lachnea cretea shows several points in common with those described by Dodge for various species of Ascobolus and Ascophanus. It differs from these in its branched extremity and in the changes which take place in its transverse septa.

Branched trichogynes are well known among the Laboulbeniales (Thaxter, '96, '08), but they have not been described elsewhere among the Ascomycetes. The arrangement in Lachnea cretea may represent, so to speak, a last effort to come into contact with an antheridium, or it may indicate the transformation of the trichogyne into a vegetative hypha. On the other hand, branching may very well have occurred when normal fertilization still took place.

Lachnea cretea adds another to the series of discomycetous forms, the investigation of which in recent years has served to break down the distinction previously drawn (Fraser and Chambers, '07) between the archicarp of the Discomycetes on the one hand and that of the Pyrenomycetes and Lichens on the other. It is now clear that, whereas Pyronema confluens, Humaria gramulata, and sundry other Discomycetes possess a spherical ascogonium which does not undergo septation, yet a number of forms as typically discomycetous show a septate ascogonial region.

Moreover, in view of the very large pores found between the ascogonial cells, there seems no longer any reason to assume that, in normally fertilized forms, the ascogonial region was necessarily unicellular at the time of union of the male and female nuclei. For all practical purposes, the multicellular ascogonial region in Lachnea cretea is a single cell, and male nuclei could readily have passed from one end of it to the other.

We have thus at present three types of discomycetous ascogonium: the single spherical cell which does not become septate (Pyronema), the single narrow cell which undergoes septation after fertilization or its equivalent (Ascodesmis), and the multicellular ascogonial region (Lachnea cretea). There is evidence of relationship between the first two forms (Claussen, '12), the second being probably the more primitive and showing a closer resemblance to the presumably primitive Aspergilliaceae (Fraser and Chambers, '07). The third is more difficult to place.

Nevertheless, the morphology of Lachnea cretea does something to suggest a relationship between this type and the Plectascineae. When young, the archicarp of Lachnea cretea closely resembles that of Aspergillus herbariorum, but it becomes differentiated by the development of the long, septate trichogyne, and of the septate ascogonial region. Further, the struc- 
ture of the fruit in its early stages differs little from that of a young perithecium. In both we find an outer protective sheath and a series of inner layers which are differentiated by their inner walls and denser contents. In Lachnea cretea, as in other Discomycetes, the thinner layers grow upwards to form paraphyses, thrusting the outer sheath wide open; but it seems probable that this arrangement is secondary, and that in Aspergillus and its allies more primitive.

It remains for further investigation to determine whether all the forms in which a widely open fruit is produced-that is to say, the typical Discomycetes-are monophyletic, or whether they have arisen along diverse lines. For the moment, the value of the archicarp as a criterion is not quite clear.

Possibly the most useful piece of information derived from the study of Lachnea cretea is the fact that the septa of the trichogyne break down. Pores amply large for the passage of male nuclei are formed, and thus the multicellular character of this organ no longer appears to impose a barrier in the way of normal fertilization. It is much to be regretted that this process was not found to occur in the material under investigation.

In the last few years a considerable mass of literature has accumulated around the question of the behaviour of the sexual nuclei in the Ascomycetes and the related problem of the divisions in the ascus.

Fusion of male and female nuclei in pairs in the ascogonium has been described and figured in various Mildews (Harper, '95, '96, '05), and, among Discomycetes, in Pyronema confluens (Harper, '00) and Ascodesmis nigricans (Claussen, '05). Pseudapogamous fusion of female nuclei in pairs has been recorded in Aspergillus repens (Dale, '09), in Humaria granulata (Blackman and Fraser, '06), in Lachnea stercorea (Fraser, '07), in Ascobolus furfuraceus (Welsford, '07), and in Ascophamus carneus (Cutting, '09), and a corresponding fusion of vegetative nuclei, in the absence of a functional ascogonium, has been seen in Humaria rutilans (Fraser, '08) and in Helvella crispa (Carruthers, '11), and evidence of the same process has been found in Polystigma rubra (Blackman and Welsford, '12).

On the other hand, Claussen in Pyronema confluens ('07, '12) and Schikorra in Monascus spp. ('09) have observed the association of the sexual nuclei in pairs in the ascogonium, but have described their fusion as delayed till, travelling and dividing side by side, they at last reach the ascus and there unite. Faull ('12) in an apogamous species of Laboulbenia has described a comparable state of affairs. The fusion in the ascus is regarded by these authors as the completion of the sexual act.

It must be recognized that the fusion in the ascogonium may be readily overlooked even in fairly large forms, but some other criteria are of assistance in determining whether it has occurred. 
Harper ('10) calls attention to the marked increase in size of the nuclei in the ascogonium in connexion with fertilization. In his opinion, judging from the size of the nuclei in Claussen's figures of young ascogenous hyphae, their fusion has already taken place. To a certain extent, changes in bulk may be accounted for by growth, but growth alone does not explain such differences between neighbouring nuclei as are shown by Blackman and Fraser ('06) in the ascogonium of Humaria granulata (Figs. I4, I6, \&c.) or by Cutting ('09) in that of Ascophamus carneus (Fig. 9).

Both Claussen and Faull have attached importance to the conjugate arrangement of the nuclei in the ascogenous hyphae as indicating that each pair represents an associated male and female nucleus. There is no doubt that a conjugate arrangement is common in the most diverse parts of certain Ascomycetes. It has been described in the last few cells of the ascogenous hyphae in a large variety of forms by many authors (Maire, '03, '05 ; Brown, '10, \&c., \&c.), by McCubbin ('10) in the vegetative hyphae of Helvella elastica, by Carruthers ('11) in the paraphyses of Helvella crispa, by Nichols ('96) in the germ tubes of the ascopores of Ceratostoma brevirostre, and by Massee ('05) in the conidial mycelium of Hypomyces perniciosum, and in some other forms.

But there is nothing to show that it depends on a previous association of sexual nuclei or of their representatives, and in the upper reaches of ascogenous hyphae it may well be explained by the prospective fusion in the ascus-whatever the significance of that curious process.

A more critical question is the arrangement in the ascogenous hyphae at their first formation. Claussen figures these hyphae in Pyronema as multinucleate, the nuclei being arranged more or less regularly in pairs. It is very difficult to think of an attraction which, while not strong enough to bring about fusion, yet holds a pair of sexual nuclei together in a multinucleate organ, where, to judge from Claussen's figures, they may be not even in contact and where they may be equally near to members of another pair. Such an arrangement seems to the writer to require overwhelming proof. It is not at all comparable to that of the Uredineae, where each pair of conjugate nuclei is isolated in a separate cell (Maire, '11, \&c., \&c.). In the Mildews, where normal fertilization takes place and where the ordinary cells are uninucleate, thus making a paired arrangement much easier to detect than in coenocytic species, the conjugate condition has not been observed (cf. Harper, '05, p. I9).

It may be noted in this connexion that vegetative nuclear fusions, among which that in the developing ascus might well be grouped, have been recorded in the cells which give rise to the paraphyses in Leotia (Brown, '10), in the young hairs of Lachnea albo-spadicea (Massee, '97), in the quadrinucleate ascus of Humaria rutilans (Fraser, '08), and in the conidia of Hypomyces (Massee, '05). The phenomenon of conjugate division is probably 
but a special example of the very general fact that nuclei present in the same cell usually divide simultaneously.

A third criterion in relation to the behaviour of the sexual nuclei lies in the reduction-processes in the ascus. It is now recognized that the first and second divisions constitute a meiotic phase compensating the sexual fusion. A second reduction, called brachymeiotic, has been described in the third division for several species, and must, where it occurs, obviously correspond to a second fusion, that in the ascus.

In its simplest form, as in Humaria rutilans (Fraser, '08), Lachnea stercorea (Fraser and Brooks, '09), and Helvella crispa (Carruthers, '11), this process consists in the appearance at the poles of the third spindle of a number of chromosomes half that seen in the first and second divisions in the ascus and in the prophase of the third. It is thus essential that the third telophase should be studied. Claussen ('12), though he denies the occurrence of brachymeiosis, omits to figure this critical stage in such a way that the chromosomes can be counted.

Faull ('12), who also opposes the idea of a second reduction, seems to have misunderstood the position. 'Fraser and her co-workers', he says (p. 347), 'state that they have detected in certain forms indications of the theoretical second reduction.' Now these authors, rightly or wrongly, have quite definitely recorded and figured the occurrence of a brachymeiotic reduction of the chromosomes, the 'indication' in question being that the chromosomes are half as numerous in the third teleophase as in that of the first division in the ascus.

They have suggested an explanation (Fraser and Welsford, '08) of the forms in which, as in Phyllactinea, an evident change in the chromosome number does not occur.

It is not proposed to enter here into details which have already been discussed, but it is perhaps worth while to place on record that a reexamination of the preparations in question has confirmed the writer in the view that an actual numerical change, whatever its significance, takes place in connexion with the third division in the ascus.

Faull adds (p. 347) that 'Guillermond, Dangeard, Maire, Brooks', himself, 'Claussen, as also Harper, have found no second reduction in the many forms examined by them.'

This statement is open to misconception. Dangeard in Ascobolus furfuraceus (Botaniste, vii, 1907, pp. $3^{\mathrm{I} 6-17}$ ) and in Pyronema confluens (Botaniste, vii, 1907, p. 284), and Maire in Morchella esculenta (Annales Mycologici, iii, 1905. pp. I35-6), in Peziza vesiculosa (Annales Mycologici, iii, I905, p. 134), and in Galactinia succosa (Annales Mycologici, iii, I905, pp. I 30-2), both found a condition corresponding to that later described as brachymeiosis. Brooks (Annals of Botany, xxiv, I9I0, p. 598) affirms that he was unable to determine whether the reduction he observed in Gnomonia 
erythrostoma was meiotic or brachymeiotic, and Harper (Publ. Carnegie Inst. of Washington, No. 37, pp. 82-4) states clearly that he regards the divisions in the ascus of Phyllactinea corylea as bringing about two reductions.

The study of the first and third divisions, and especially of the third telophase, in forms with large nuclei, is essential for the satisfactory determination of this question.

\section{SUMMARY.}

I. The archicarp of Lachnea cretea arises as a branch from one of the main hyphae and forms a coil of two or three turns.

2. From the hypha bearing the archicarp and from neighbouring hyphae, branches grow out to form a sheath.

3. The archicarp becomes differentiated into three regions, the multicellular stalk, the coiled, multicellular ascogonial portion, and the septate trichogyne. The latter elongates considerably, and ultimately branches. No antheridium was observed.

4. The trichogyne becomes emptied, its transverse septa break down, and the pores are closed by homogeneous pads. It suggests itself that the trichogyne has only recently ceased to function.

5. The ascogonial region contains numerous nuclei. Very large pores are found between its constituent cells, and the nuclei pass freely from one cell to another. Ascogenous hyphae arise from the several cells.

6. Asci are formed in the usual way. The nuclei show about eight chromosomes in the first division.

7. The nuclei were too small to allow a satisfactory study of their behaviour either in the ascogonium or in the later divisions in the ascus, the significance of which is discussed.

8. In the structure of its archicarp Lachnea cretea differs markedly from the other investigated species of Lachnea. It resembles several of the Ascobolaceae, and shows some points in common with Aspergillus.

\section{LIST OF PAPERS.}

1. Blackman, V. H., and Fraser, H. C. I. ('06): On the Sexuality and Development of the Ascocarp in Humaria granulata. Proc. Roy. Soc., London, B., lxxvii, p. 354.

2. - and Welsford, E. J. ('12): The Development of the Perithecium of Polystigma rubrum. Ann. Bot., xxvi, p. 76I.

3. Brooks, F. T. ('10): The Development of Gnomonia erythrostoma, Pers. The Cherry Leat Scorch-disease. Ann. Bot., xxiv, p. $5^{8} 5$.

4. Brown, W. H. ('10): The Development of Leolia. Bot. Gaz., 1, p. 443. 
5. Carruthers, D. ('11): Contributions to the Cytology of Helvella crispa. Ann. Bot., xxv, p. 243 .

6. Claussen, P. ('05): Zur Entwicklungsgeschichte der Ascomyceten, Boudiera. Bot. Zeit., lxviii, p. I.

7. ('12): Zur Entwicklungsgeschichte der Ascomyceten, Pyronema confluens. Zeitschr. für Bot., iv, p. I.

8. Cutring, E. M. ('09): On the Sexuality and Development of the Ascocarp in Ascophamus carneus. Ann. Bot., xxiii, p. 399.

9. Dale, E. ('09): On the Morphology and Cytology of Aspergillus repens. Ann. Myc., vii, p. 2 I 5.

10. DANGeARD, P. A. ('07): Recherches sur le développement du périthèce chez les Ascomycètes. Botaniste, $x, p . I$.

11. Dodge, B. O. ('12): Methods of Culture and the Morphology of the Archicarp in certain Species of the Ascobolaceae. Bull. Torrey Bot. Club, xxxix, p. I 39.

12. FaUll, J. H. ('12): The Cytology of Laboulbenia chaetophora and L. Gyrinidarum. Ann. Bot., xxvi, p. 325 .

13. Fraser, H. C. I. ('07): On the Sexuality and Development of the Ascocarp in Lachnea stercorea. Ann. Bot., xxi, p. 349 .

14. ('08): Contributions to the Cytology of Humaria rutilans. Ann. Bot., xxii, p. 35 .

15. Ann. Myc., v, p. 419 .

16. - and Welsford, E. J. ('08): Further Contributions to the Cytology of the Ascomycetes. Ann. Bot., xxii, p. 465 .

17. - and Brooks, W. E. ST. J. ('09) : Further Studies on the Cytology of the Ascus. Ann. Bot., xxiii, p. 537.

18. Harper, R. A. ('95): Die Entwicklung des Peritheciums bei Sphaerotheca castagnei. Ber. d. Deutsch. Bot. Ges., xiii, p. 475 .

19. ('96): Über das Verhalten der Kerne bei der Fruchtentwicklung einiger Ascomyceten. Jahrb. für wiss. Bot., xxix, p. ${ }_{5} 6$.

20. ('90): Sexual Reproduction in Pyronema confuens, \&c. Ann. Bot., xiv, p.32I .

21. ( $(05)$ : Sexual Reproduction and the Organization of the Nucleus in certain Mildews. Publ. Carnegie Inst. of Washington, No. 37, p. I.

22. ('10): Nuclear Phenomena of Sexual Reproduction in Fungi. Am. Naturalist xliv, p. 533 .

23. MaIre, R. ('03): Recherches cytologiques sur le Galactinia succosa. Comptes rendus, cxxxvi, p. 769 .

24. ('05): Recherches cytologiques sur quelques Ascomycètes. Ann. Myc., iii, p. I 23.

25. ('11): La Biologie des Urédinales. Prog. Rei Bot., iv, p. I09.

26. Massee, G. ('97) : A Monograph of the Geoglossaceae. Ann. Bot., xi, p. 225.

27. ('05): On the Presence of Binucleate Cells in the Ascomycetes. Ann. Bot., xix, p. 325 .

28. McCubbin, ('10): Development of the Helvellineae. Bot. Gaz., xl, p. I95.

29. Nichols, M. A. ('96): The Morphology and Development of Certain Pyrenomycetous Fungi. Bot. Gaz., xxii, p. 301 .

30. Schikorra, W. ('09) : Über die Entwicklungsgeschichte von Monascus. Zeitschr. für Bot., i, p. 379 .

31. Thaxter, R. ('96): Contributions towards a Monograph of the Laboulbeniaceae, Pt. I. Mem. Am. Acad. Arts and Sciences, xii, No. iii, p. 195.

32. ('08): Contributions towards a Monograph of the Laboulbeniaceae, Pt. II. Mem. Am. Acad. Arts and Sciences, xiii, No. vi, p. 219.

33. WeLsFord, E. J. ('07) : Fertilization in Ascobolus furfuraceus. New Phyt., vi, p. I36. 


\section{EXPLANATION OF PLATES XLII AND XLIJI.}

Illustrating Dr. H. C. I. Gwynne-Vaughan's paper on Lachnea cretea.

\section{PLATE XLII.}

Fig. I. Mature ascocarp. $\times$ Ioo.

Fig. 2. Very early stage in development of archicarp and of investing hyphae. Uncut. $\times 500$. $\times 500$.

Fig. 3. Rather older; the tip of the archicarp is growing out to form a trichogyne. Uncut.

Fig. 4. Later stage of same; development of rooting hyphae. Uncut. $\times 500$.

Fig. 5. Young fruit; the ascogonial region of the archicarp is enclosed in the sheath and the branched trichogyne protects; the latter is almost empty and the pads have appeared on its crosswalls. Uncut. $\times 500$.

Fig. 6. A rather older fruit, showing the elaborately branched trichogyne. Uncut. $\times 500$.

Fig. 7. Section showing a very young archicarp. $\times 666$.

*Fig. 8. Older stage in section; the coil appears foreshortened, being seen from one end. The trichogyne is developing; the nuclei are crowded. $\times 666$.

Fig. 9. Somewhat older archicarp ; trichogyne becoming emptied. $\times 666$.

Fig. Io. Section through a young fruit to show development of sheath and its relation to the hypha bearing the archicarp. $\times 666$.

*Fig. I I. Coiled archicarp, showing stalk, coiled ascogonial region with numerous nuclei, and long, branched tricogyne. Pads have developed on most of the septa of the trichogyne, but through a septum near the ascogonial region a mass of granular substance is continuous from cell to cell. $\times 666$.

\section{PLATE XLIII.}

*Fig. I2. Part of an older fruit, showing an ascogonial cell with numerous nuclei and a long, empty trichogyne. $\times 666$.

Fig. I3. Two ascogonial cells in continuity. Nuclei passing from one to the other. $\times$ I,000.

*Fig. I4. Three ascogonial cells united by very large pores and almost empty. Above, asci are developing. $\times 666$.

Fig. 15. Group of ascogenous hyphae. $\times 2,000$.

Fig. 16. Prophase of first division in ascus, showing about eight chromosomes. $\times 2,000$.

Fig. I7. Metaphase of first division in ascus. $\times 2,000$.

* Figures marked thus have been drawn from two or more consecutive sections. 


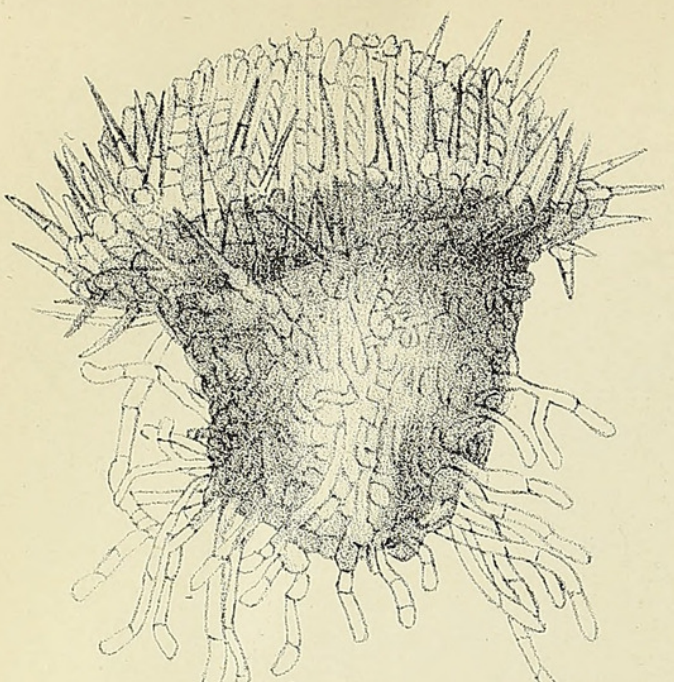

1.
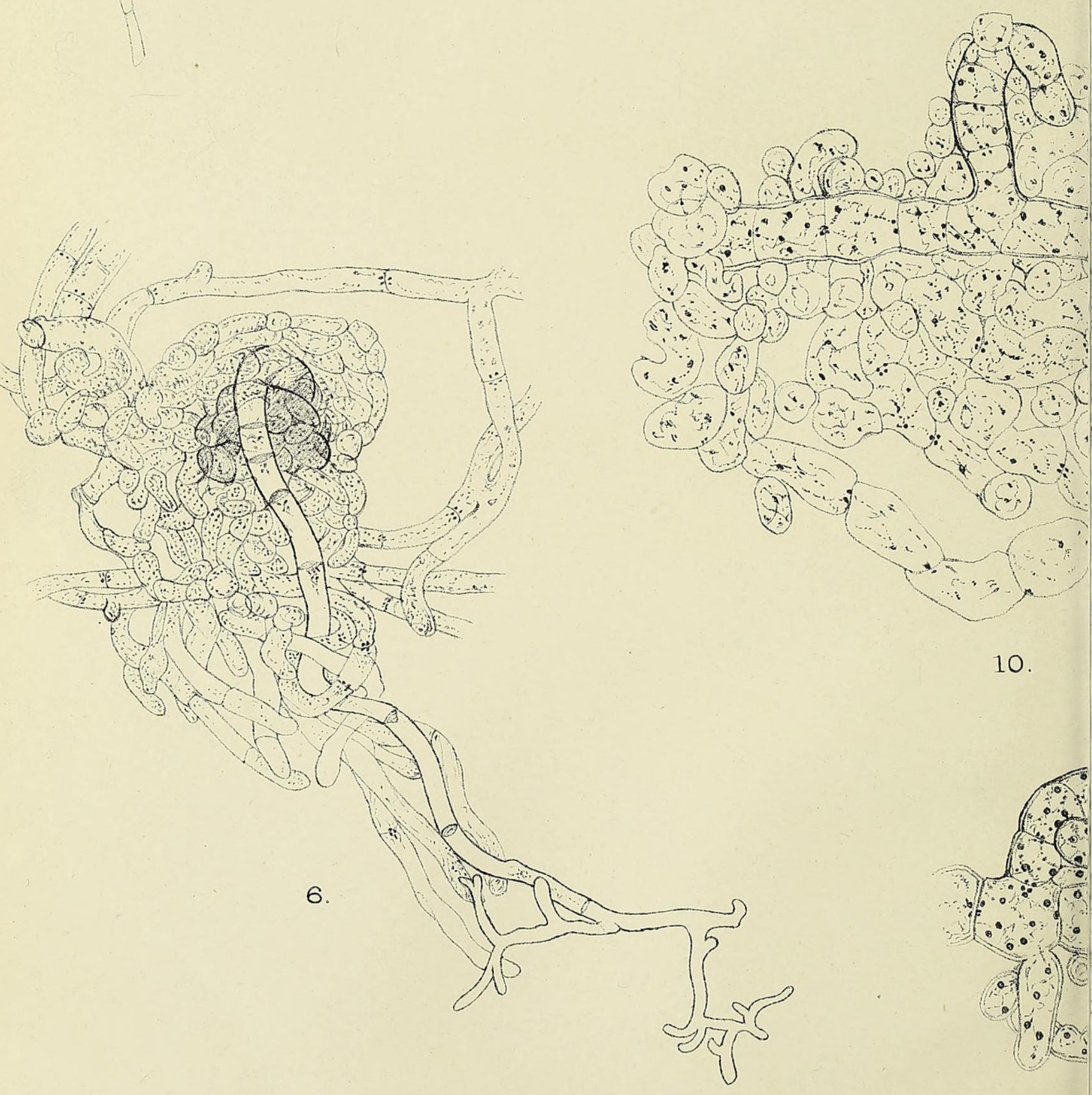

FRASER - LACHNEA CRETEA 


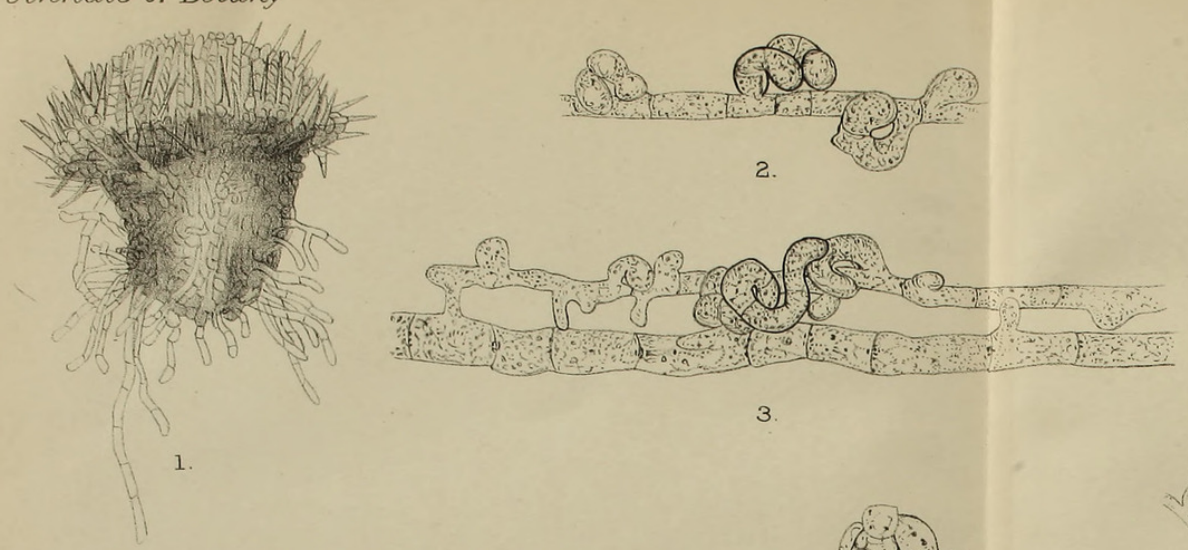

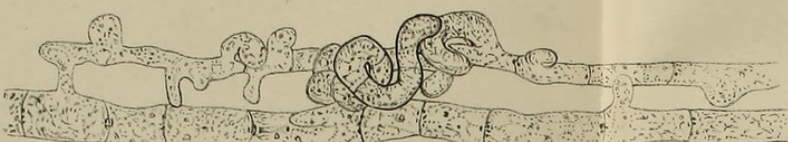

3

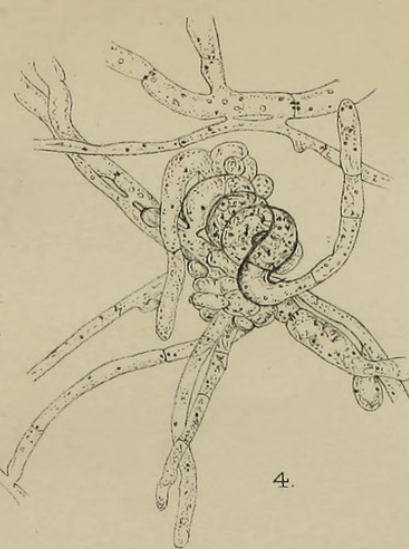

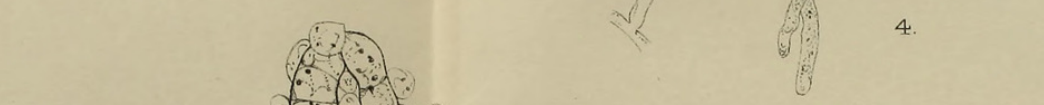
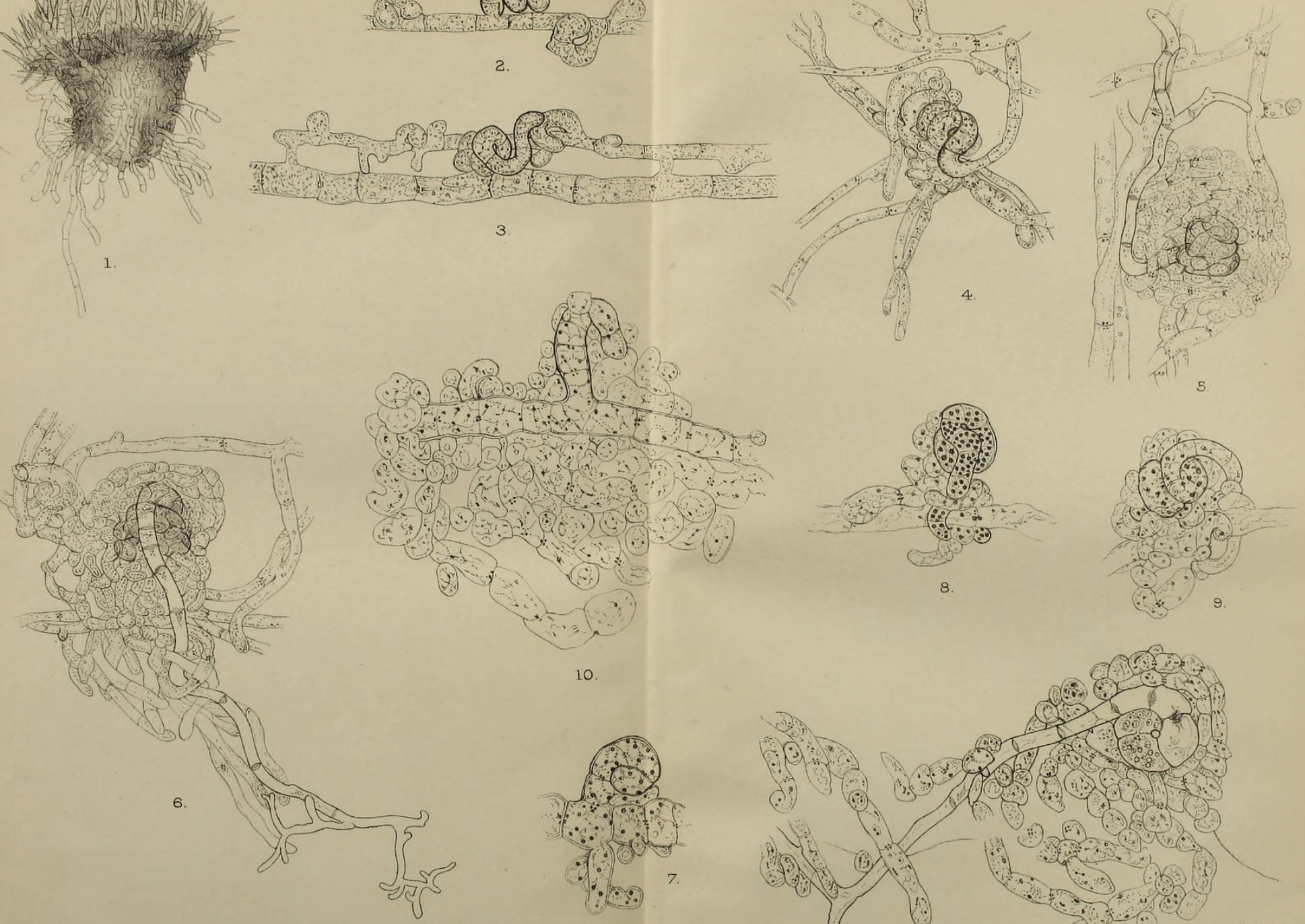

$\therefore \circ(\sqrt{0}) \cdot 0$

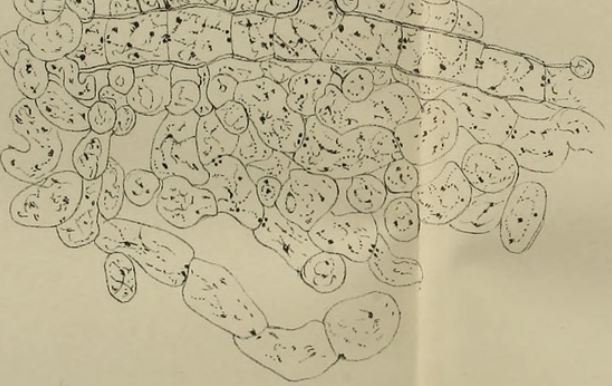

10.

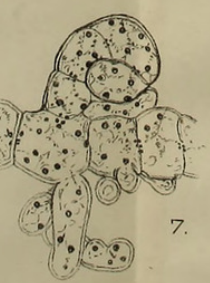

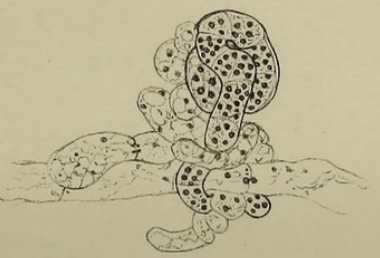

8.
9.
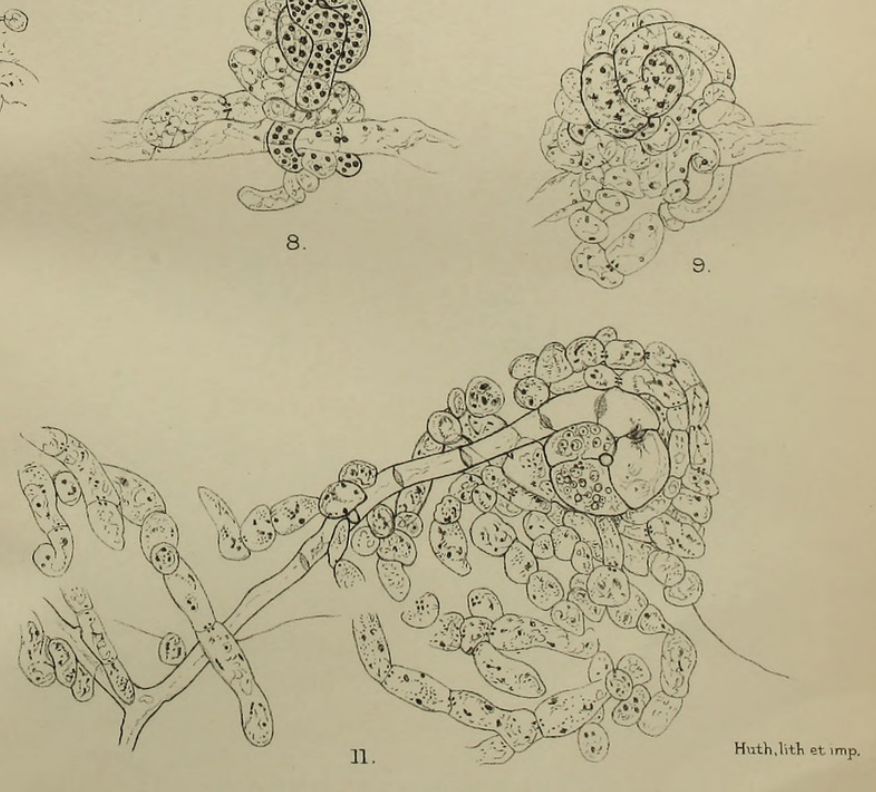
Annals of Botany
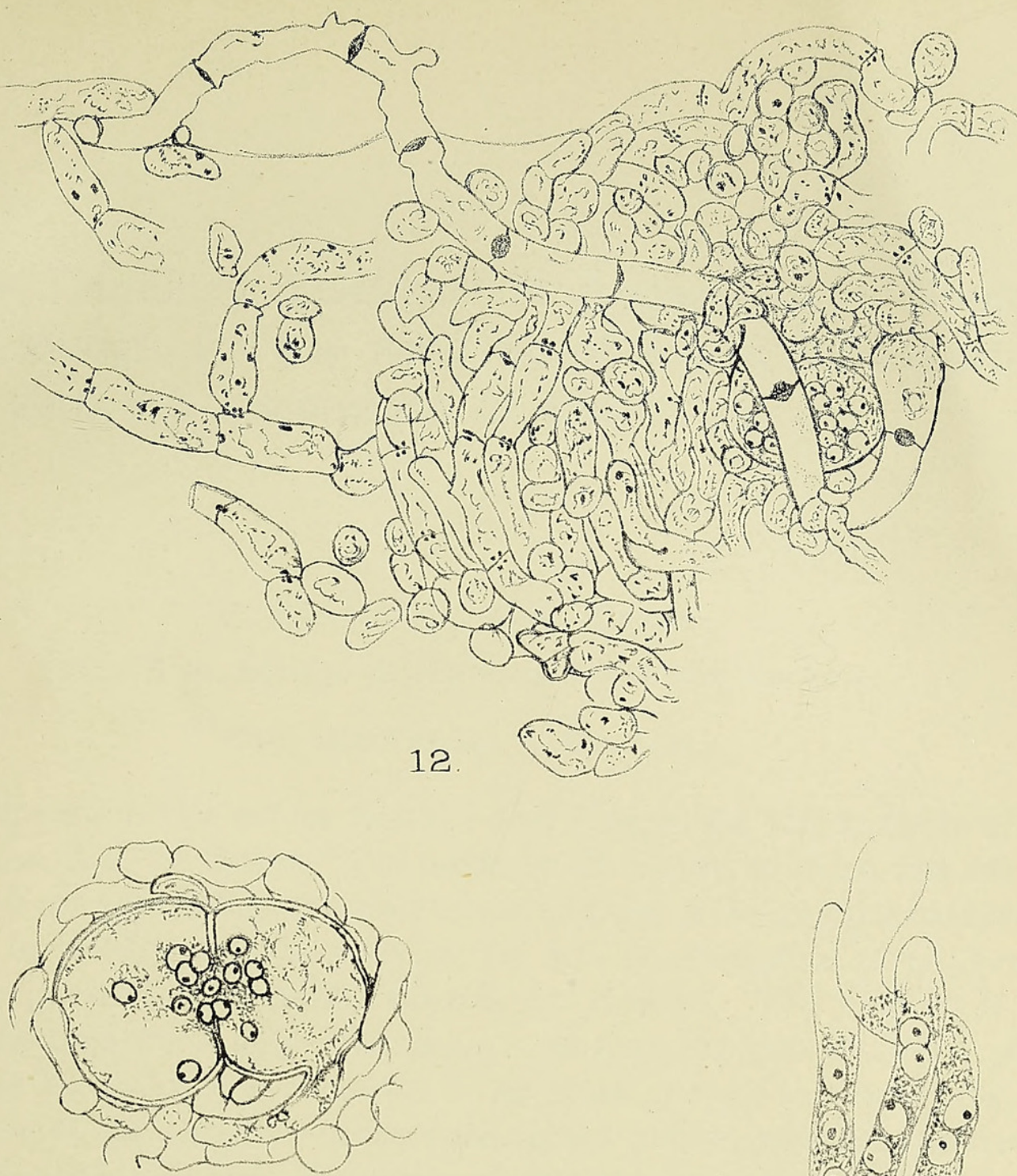

13
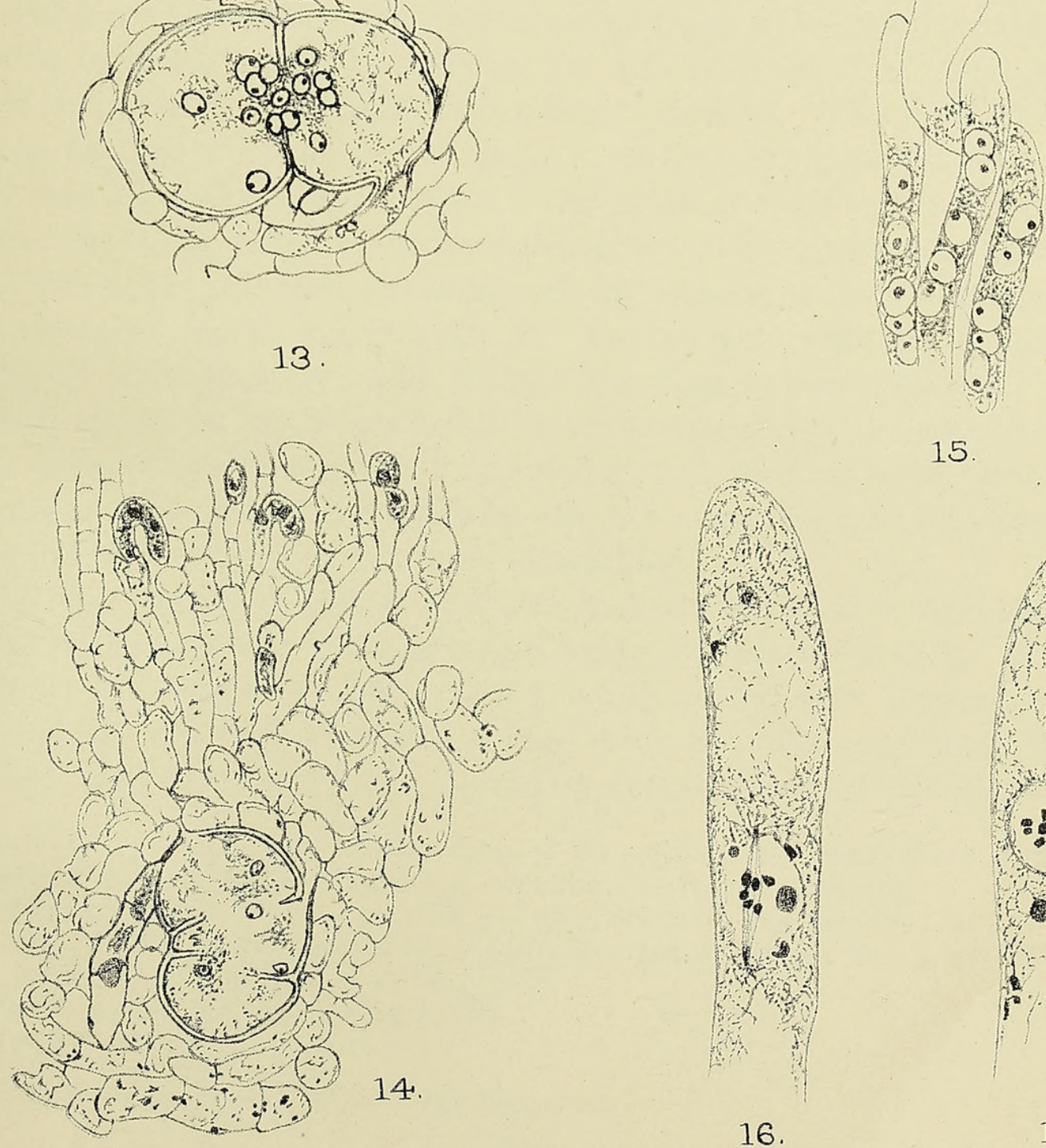

15

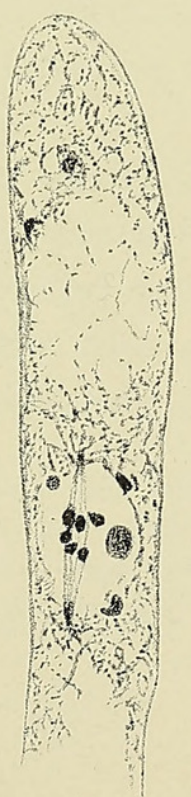

16.

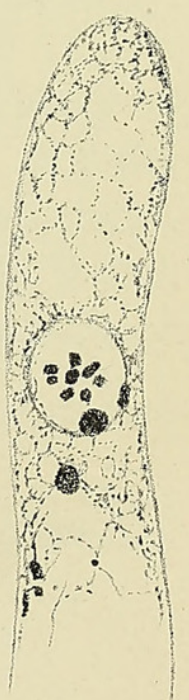

17.

Huth, lith.et imp.

FRASER - LACHNEA CRETEA. 


\section{$2 \mathrm{BHL}$ Biodiversity Heritage Library}

Gwynne-Vaughan, H. C. I. 1913. "The development of the ascocarp in Lachnea cretea." Annals of botany 27, 553-563.

https://doi.org/10.1093/oxfordjournals.aob.a089475.

View This Item Online: https://www.biodiversitylibrary.org/item/237410

DOI: https://doi.org/10.1093/oxfordjournals.aob.a089475

Permalink: https://www.biodiversitylibrary.org/partpdf/319988

\section{Holding Institution}

Smithsonian Libraries

\section{Sponsored by}

Biodiversity Heritage Library

\section{Copyright \& Reuse}

Copyright Status: Not in copyright. The BHL knows of no copyright restrictions on this item.

This document was created from content at the Biodiversity Heritage Library, the world's largest open access digital library for biodiversity literature and archives. Visit BHL at https://www.biodiversitylibrary.org. 